\title{
Fish and shrimp waste management at household and market in Bushehr, Iran
}

\author{
Masoumeh Ravanipour ${ }^{1,2} \cdot$ Razieh Bagherzadeh $^{3} \cdot$ Amir Hossein Mahvi $^{1,4}$ (D)
}

Received: 13 August 2020 / Accepted: 18 March 2021 / Published online: 29 March 2021

๑) Springer Japan KK, part of Springer Nature 2021

\begin{abstract}
The aim of this study was to investigate the estimation and management of fish and shrimp wastes in Bushehr province. Twopart questionnaire including the demographic information, and fish and shrimp waste disposal method were completed for 91 stores and 636 households. The quantity of generated wastes was estimated based on the 3 different Scenarios. In addition, the waste generation factor were calculated for common fish and shrimp species. Results showed the waste generation factor for fish and shrimp equal to 32.67 and $42 \%$, respectively. The total quantity of fish- and shrimp-generated wastes in Bushehr province was estimated to be 29,388 tons per year, of which the quantity of generated waste by stores and by households was 3731 tons per year (16 ton per capita per year) and 8804 tons per year (34 kg per capita per year), respectively. The remaining quantity is related to other unaccounted sectors such as fish industries. Moreover, the biogas production potential from an anaerobic digestion were estimated 2,675,400 $\mathrm{m}^{3}$ per year, which is equivalent to $16,052 \mathrm{MWh}$. In addition, the biodiesel production potential was obtained equivalent to $19 \mathrm{kt}$, which is about $4.2 \%$ of the total diesel fuel requirement of the province in 2016 .
\end{abstract}

\section{Graphic abstract}

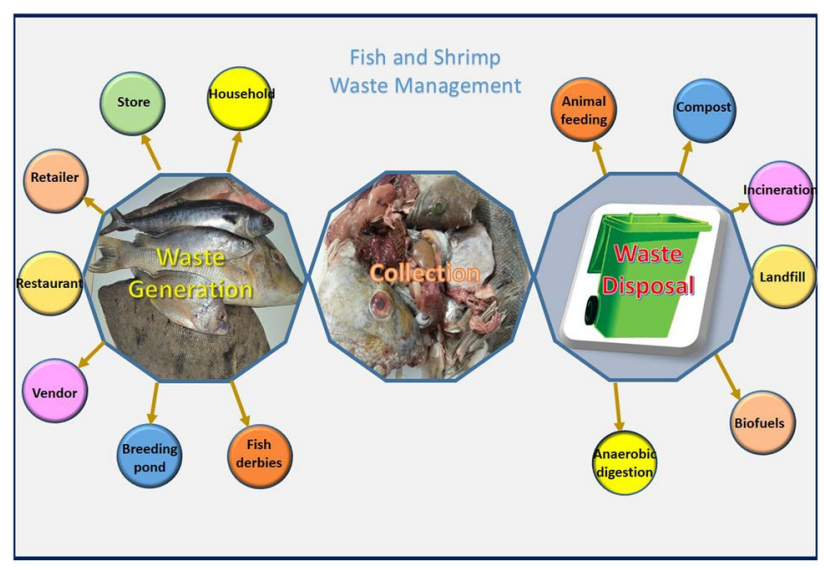

Keyword Fish waste $\cdot$ Shrimp waste $\cdot$ Household $\cdot$ Store $\cdot$ Iran

Amir Hossein Mahvi

ahmahvi@yahoo.com

Extended author information available on the last page of the article 


\section{Introduction}

With the population increase in the world and especially in developing countries, there is a need to supply food demand. On the other hand, the world has faced certain challenges because of their produced wastes, which have been discussed as an important threatening factor to the sustainability of developing countries [1-3]. According to an estimation provided by the Food and Agriculture Organization of the United Nations (FAO) in 2013, about 1.3 Gtons of different foods are wasted in the world, annually [4]. It is also projected that by 2050 , the quantity of produced food will increase up to $60 \%$ higher than 2005/2007 [4] and up to $49 \%$ compared to 2012, which is due to economic and demographic growth and changes in human lifestyles and quality of life $[5,6]$.

In recent years, following the increase in importance and role of seafood in human health, their consumption has also increased [7, 8], such that fish consumption per capita in the last 45 years has doubled around the world $[9,10]$. According to FAO, global fish production was 167 million tons (146 million tons was for human consumption) and per capita consumption reached $20 \mathrm{~kg}$ in 2014 [7, 11, 12]. Iran's fish production was about 1 million tons and per capita consumption reached $12 \mathrm{~kg}$ in 2018 [13, 14]. Furthermore, the quantity per capita fish consumption in the world and Asia was 19 and $23 \mathrm{~kg}$, respectively [15]. Iran's fisheries GDP was equal to 4 billion USD in 2013 which was $4 \%$ of agriculture GDP (104 billion USD) [16].

Fish waste refers to those parts of fishes which are not eaten as food. It usually includes head, tail, abdomen and intestines, scales, fins, skin, and bones [7, 8, 17, 18]. Fried fins of fishes may be used in some countries; anyway for a country like Japan where a large quantity of freshly prepared fish (without skin, bones, and fins) is consumed daily (Shashami), the production of large quantities of fish wastes in fish-processing plants and stores is not unexpected [3]. In addition, most processing operations are take place on beaches and ports [7]. Anyhow, fish waste disposal in the seas or coastal waters of the ports causes environmental pollution, the effect on the aquatic food chain, and ultimately increases in algal bloom formation, which is extremely dangerous to the health of local ecosystems [7, 11]. However, some parts of fish and shrimp could be collected as chitosan and applied for pollutants removal from contaminated aqueous solutions [19-21].

In general, fish waste is produced from different parts: in households, restaurants, fishing at the sea, fish stores, fishprocessing plants or retail level, and aquaculture activity [7]. It should be noted that the disposal of these wastes also leads to the spread of pollution [3]. In Spain, such organic wastes account for $49 \%$ of all municipal solid waste, which most of them are buried in landfills [22]. However, the effects of population growth, public participation, facilities, etc., have faced some developing countries with serious challenges in food waste management [2].

There are many different management methods for food and fish wastes, including animal feed, anaerobic digestion, incineration, production of biogas and biofuels, composting, and finally landfill. In most of them, waste is considered a valuable source for energy production such as heat and electricity [2, 6, 23]. In a study conducted by Kafle et al. (2013), fish waste with a mixture of brewery grain waste (BGW) and bread waste (BW) was used to produce biogas [9]. In the study of Mshandete (2004), fish wastes were examined to digest separately and mixed with sisal pulps to obtain the biogas [24]. In recent years, due to population growth and the need for a different source of energy, studies have shown a greater tendency to survey on biofuel production from food wastes, including aquatic waste [25-27].

Since improper and uncontrolled food waste disposal can pose risks to the economy, public and environmental health, quantification and management of them are a priority for communities $[2,6]$. Accordingly, this study aimed to investigate the estimation and management of fish and shrimp wastes in Bushehr province located in the Persian Gulf coastline with emphasis on households and stores, from 2018 to 2019. By the way, other generated wastes as fish and shrimp industries and being transferred to other place and shrimp breeding and cultural ponds, vendors, etc. were excluded from this study estimation.

\section{Materials and methods}

\section{Study area}

Iran is one of the countries located in the Middle East region in South-east Asia. Its area is $1,648,195 \mathrm{~km}^{2}$ with 83 million people according to the latest national census. The existence of many different saline and freshwater resources has made it as a country with high potential in production and breeding of aquacultures. Bushehr province is located in the Southwestern of Iran with geographical coordinates N28,9576 ${ }^{\circ}$ latitudes and $\mathrm{E} 50,8371^{\circ}$ longitudes, and is bounded by the Persian Gulf in the West. Based on the statistics (2016), it has a population about $1,163,400$ million, and a warm climate, which is hot and humid in the coastal. The Persian Gulf and the Oman Sea is approximately $1800 \mathrm{~km}$ long. Bushehr province has 10 counties that Bushehr, Ganaveh, Deylam, Tangestan, Deyr, Kangan, Asaluyeh, and few parts of Dashti, are bordered more than $600 \mathrm{~km}$ by the Persian Gulf (Fig. 1) [16, 28, 29]. 


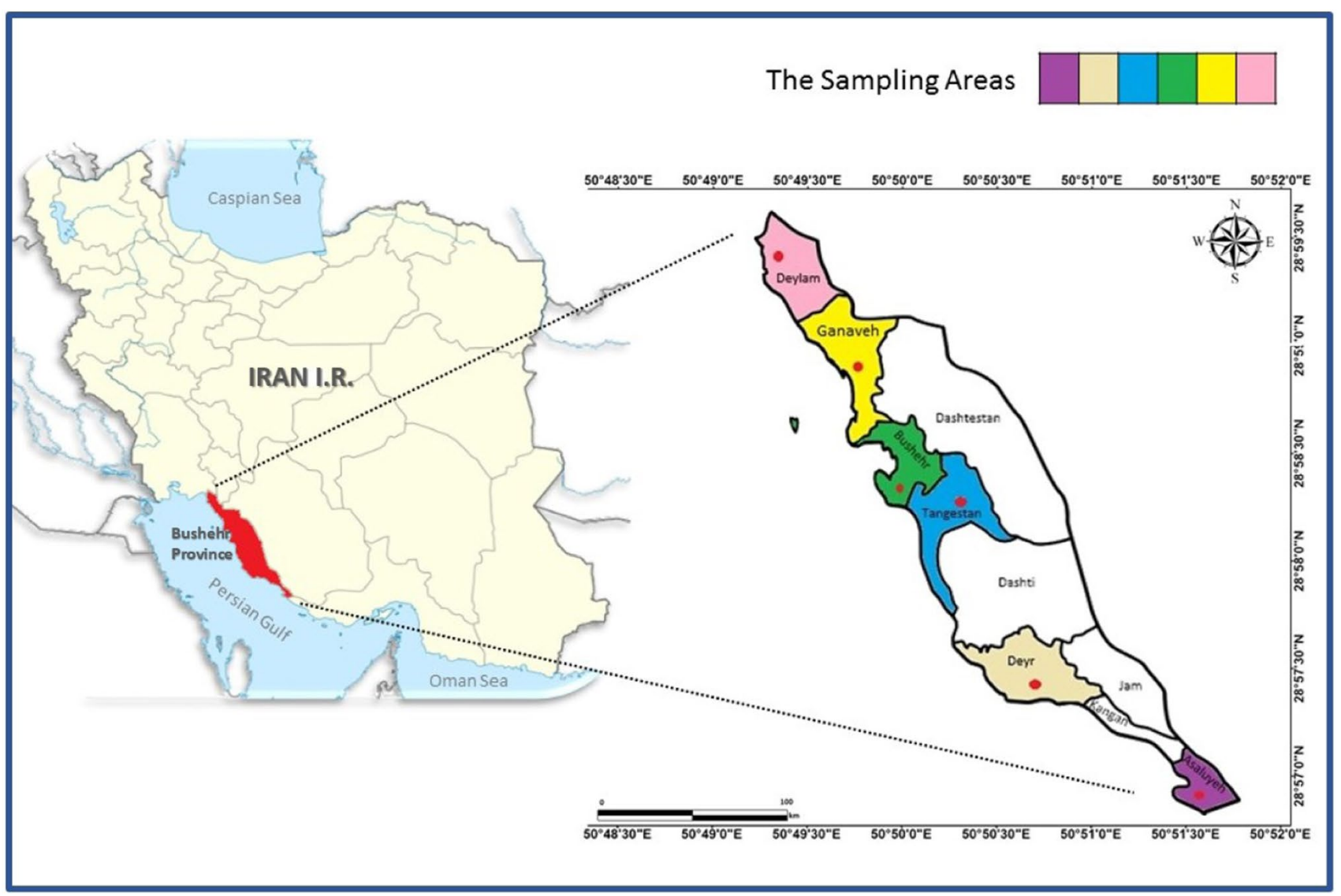

Fig. 1 Location of Bushehr province, Iran

\section{Study sampling}

A descriptive cross-sectional study performed to determine the current status of fish and shrimp waste management. According to the 185,974 urban households in the province, considering the level of confidence equal to $95 \%$ and the relative accuracy of 0.05 , about 383 samples were determined using the Cochran's formula. Based on the coefficient of 1.5 that was considered due to cluster sampling, total questionnaires were distributed to 636 people. Science Bushehr province is a peninsula with 10 counties, we used 6 port counties randomly to our study included: Bushehr, Ganaveh, Tangestan, Asaluyeh, Deyr, and Deylam. However, in each county, samples were taken from different areas of the city based on the number of health care centers. The samples were selected by convenience sampling. In addition, every fish and shrimp stores that were willing to cooperate in this research were included.

A two-part questionnaire including demographic information and four questions related to fish and shrimp waste were completed for intended stores and households. Since based on our knowledge, no similar study has been already done, the relevant questions were designed using the literature and a self-administered questionnaire. The maximum time for completing each questionnaire was about $10 \mathrm{~min}$. Additional data are given in Online Resource 1 and Online Resource 2.

\section{Estimation of fish and shrimp waste production}

\section{Triple waste estimation scenarios}

Three scenarios were used to estimate the fish- and shrimpproduced waste. In Scenario 1, the produced wastes quantity was calculated based on the total fish and shrimp sold in the studied stores. It was difficult to access all fish and shrimp stores for questioning and weighting the total produced wastes, and to achieve any data from daily garbage collection services. In this regard, fish and shrimp sellers expressed their monthly (in each season of the year) sales and their 
weight of fish- and shrimp-generated wastes, approximately. In addition, a question was asked them via questionnaire about do or do not peeling fish and shrimp in their stores. In Scenario 2, the quantity of fish-and shrimp-generated wastes was calculated based on the total waste production among households. For this purpose, all needed information about fish and shrimp consumption quantity per month in each season per year, as well as information about whether or not to peel and clean the purchased fish and shrimp at home were asked via the questionnaire. In Scenario 3, according to the available official statistics of capturing and aqua-culturing rate in the whole of the province, the total quantity of waste production was estimated.

\section{Waste generation factor}

One of the required factors for estimating the fish- and shrimp-produced waste rate is the waste generation factor. To achieve this important, we had two choices to calculate it: the first choice was based on the designed questionnaire; for this purpose, some questions were asked to the sellers: "have peeling parts in your stores or have previous experience in doing so?", and if yes "how much is the approximate weight of produced waste per kilogram of fish or shrimp?" But as mentioned, this is a subjective/experimental estimation method and is not very accurate. Accordingly, the second choice was considered; in this way, in a laboratory, 6 types of the most consumed fish in the province which are stated most of them in the statistical reports of the Department of Fisheries of Bushehr province (Shilat) $[13,14]$ were purchased and after cleaning and peeling, their wastes were weighed separately with an accurate scale. In addition, for shrimp, $1 \mathrm{~kg}$ of medium-sized Persian Gulf shrimp was purchased and after peeling, the weight of different parts was measured with an accurate scale. Then, the ratio of wastes to raw parts of fish or shrimp was calculated and the waste generation factor was reported as follows:

Fish or shrimp waste generation factor (\%)

$$
=\left(\frac{\text { Ewastes }(\mathrm{g})}{\text { RRaw weight }(\mathrm{g})}\right) \times 100 \text {. }
$$

\section{Statistical analysis}

The collected data were analyzed by the software SPSS version 13 [SPSS Inc., Chicago] using Mann-Whitney and Kruskal-Wallis test. The table of frequency, mean and

Table 2 Total monthly consumption of fish and shrimp per season in households

\begin{tabular}{lllcc}
\hline Variable & Season & Total consumption & Mean & SD \\
\hline Monthly fish & Spring & 4497.7 & 7.15 & 8.22 \\
consump- & Summer & 4197.5 & 6.8 & 6.6 \\
tion (kg) & Autumn & 4171.1 & 6.7 & 7.53 \\
& Winter & 4107.2 & 6.8 & 7.67 \\
& Total & 16,909 & 26.46 & 28.18 \\
Monthly & Spring & 2355.15 & 4.45 & 6.57 \\
shrimp & Summer & 2745.3 & 4.93 & 5.64 \\
consump- & Autumn & 2352 & 4.44 & 5.42 \\
tion (kg) & Winter & 2069.9 & 4.09 & 4.88 \\
& Total & 9522.35 & 14.9 & 19.61 \\
\hline
\end{tabular}

$S D$ standard deviation
Table 1 Demographic information of households, and fish and shrimp stores

\begin{tabular}{|c|c|c|c|c|c|}
\hline \multirow[t]{2}{*}{ Variable } & \multirow[t]{2}{*}{ Level } & \multicolumn{2}{|l|}{ Households } & \multicolumn{2}{|l|}{ Stores } \\
\hline & & Number $(\%)$ & Total & Number (\%) & Total \\
\hline \multirow[t]{2}{*}{ Gender } & Male & $159(25.0)$ & 636 & $69(97.0)$ & 71 \\
\hline & Female & $477(75.0)$ & & $2(3.0)$ & \\
\hline \multirow[t]{4}{*}{ Educational level } & Illiterate & $42(6.7)$ & 626 & $15(17.6)$ & 85 \\
\hline & Diploma and under diploma & $266(42.5)$ & & $56(66.0)$ & \\
\hline & Associate degree and Bachelor & $275(43.9)$ & & $12(14.0)$ & \\
\hline & Master's degree or higher & $43(6.9)$ & & $2(2.4)$ & \\
\hline \multirow[t]{5}{*}{ Employment status } & Employed & $270(43.8)$ & 616 & - & - \\
\hline & Student & $11(1.8)$ & & - & \\
\hline & Housewife & $255(41.4)$ & & - & \\
\hline & Unemployed & $9(1.5)$ & & - & \\
\hline & Other & $71(11.5)$ & & - & \\
\hline \multirow[t]{4}{*}{ Employment duration } & $<5$ years & - & - & $22(27.5)$ & 80 \\
\hline & $5-14$ years & - & & $43(53.8)$ & \\
\hline & $15-30$ years & - & & $14(17.5)$ & \\
\hline & $>30$ years & - & & $1(1.3)$ & \\
\hline
\end{tabular}


Table 3 Total monthly sales of fish and shrimp per season in stores

\begin{tabular}{llrrrrr}
\hline Variable & Season & Min. sales & Max. sales & Total sales & Mean sales & SD \\
\hline Monthly fish sales (kg) & Spring & 20 & 10,800 & 168,985 & 1877.61 & 2314.49 \\
& Summer & 20 & 30,000 & 227,188 & 2581.68 & 4300.67 \\
& Autumn & 20 & 15,000 & 228,309 & 2565.27 & 3086.04 \\
& Winter & 8 & 24,000 & 175,638 & 2018.83 & 3891.79 \\
& Total & 75 & 55,000 & 800,120 & 8890.22 & $10,845.32$ \\
Monthly shrimp sales (kg) & Spring & 5 & 10,000 & 95,971 & 1744.93 & 2012.12 \\
& Summer & 10 & 35,000 & 265,624 & 3741.18 & 6086.04 \\
& Autumn & 5 & 8000 & 109,445 & 1954.38 & 1958.24 \\
& Winter & 5 & 15,000 & 78,352 & 1450.96 & 2373.70 \\
& Total & 31 & 54,000 & 549,392 & 7325.23 & 8969.73 \\
\hline
\end{tabular}

$S D$ standard deviation standard deviation (SD) (a measure of the amount of variation or dispersion of a set of values) was used to describe data. A significant level was considered less than 0.05 in all cases $(P<0.05)$. The $P$ value $(P)$ is a measure of the probability that shows the observed difference occurred randomly, and indicates strong evidence against the null hypothesis. When the $P$ value was less than the significance level $(\alpha=0.05)$ ( $P$ value $\leq 0.05)$, the variables have a statistically significant association and we cannot accept the null hypothesis [30].

\section{Results and discussion}

\section{Data description}

A total of 636 and 91 questionnaires were completed for households and fish and shrimp stores, respectively. The mean and standard deviation (mean \pm SD) of participating age for households was $40.5 \pm 12.4$ and for fish and shrimp stores was $40.36 \pm 12.11$. Among the households, the majority of our research participants were women $(75 \%)$ and for stores, only $3 \%$ were women. More than half of the stores' participants had 5-14 years of experience in their profession (53.8\%) (Table 1). According to the results, the highest average consumption of fish and shrimp $(\mathrm{kg} /$ month) was reported in spring and summer, respectively (Table 2). In addition, the highest average sales of fish and shrimp (kg/month) are reported in summer (Table 3). However, the analysis of demographic findings by the Kruskal-Wallis test shows only a significant difference between the level of education of illiterate people with educated people (other groups) $\left(\chi^{2}=9.67, P \leq 0.02\right)$. In addition, it shows a significant difference between people without a certain job (other cases), in contrast, people with specific occupations in summer and annual shrimp consumption of households $\left(\chi^{2}=11.95, P \leq 0.01\right)$. Moreover, there was no significant difference in the seasonal and annual fish consumption between different groups of demographic information $(P \geq 0.05)$. It seems that the
Fig. 2 Fish and shrimp waste processing in Bushehr: a measurement and $\mathbf{b}$ flow diagram for waste generation factor (a)

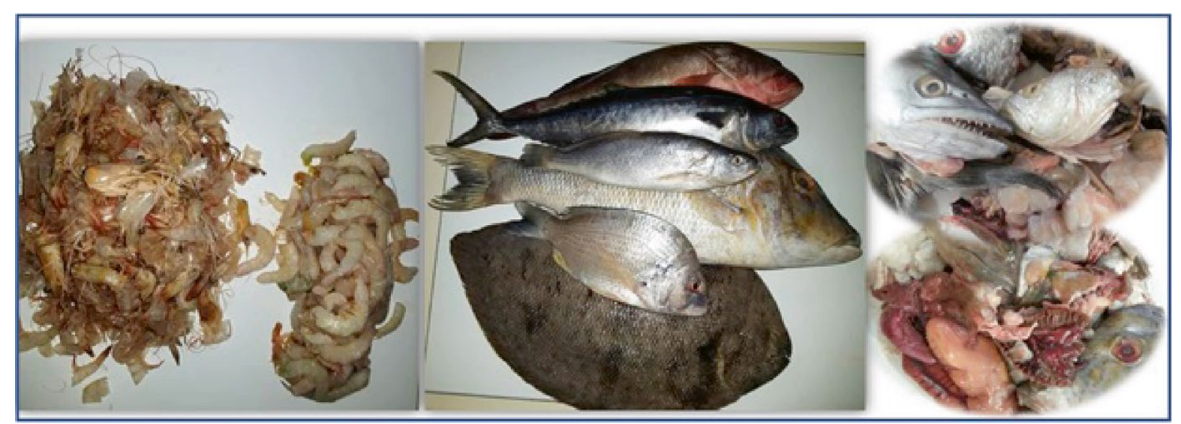

(b)

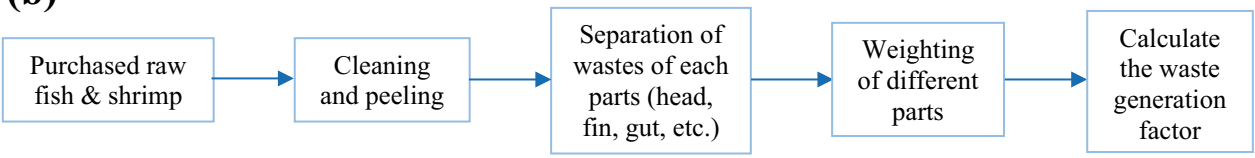


Table 4 Characteristics of fish and shrimp specimens and waste production range in Bushehr province

\begin{tabular}{|c|c|c|c|c|c|c|c|c|c|}
\hline \multirow[t]{2}{*}{ Type } & \multirow[t]{2}{*}{ Local/scientific name } & \multirow[t]{2}{*}{$\mathbf{n}$} & $\begin{array}{l}\text { Total } \\
\text { weight } \\
\text { per Unit }\end{array}$ & Gut & Head & Tail & Fin & Scales & \multirow[t]{2}{*}{ Shape } \\
\hline & & & \multicolumn{6}{|c|}{ mean (g) } & \\
\hline \multirow[t]{6}{*}{ Fish } & $\begin{array}{l}\text { Shourideh (Otolithes } \\
\text { ruber) }\end{array}$ & 4 & 480 & 48 & 69 & 18 & 6 & 9 & $E$ \\
\hline & $\begin{array}{l}\text { Shoeum (Acanthopagrus } \\
\text { latus) }\end{array}$ & 2 & 544 & 30 & 90 & 10 & 24 & 30 & \\
\hline & $\begin{array}{l}\text { Shir (Scomberomorus } \\
\text { commerson) }\end{array}$ & 3 & 495 & 32 & 42 & 6 & 10 & 0 & \\
\hline & $\begin{array}{l}\text { Hamoor (Epinephelus } \\
\text { coioides) }\end{array}$ & 2 & 670 & 44 & 120 & 15 & 16 & 12 & \\
\hline & $\begin{array}{l}\text { Koushak (Brachirus } \\
\text { orientalis) }\end{array}$ & 2 & 1200 & 65 & 90 & 0 & 0 & $182^{\mathrm{a}}$ & \\
\hline & $\begin{array}{l}\text { Shery (Lethrinus } \\
\text { nebulosus) }\end{array}$ & 2 & 1590 & 215 & 370 & 10 & 14 & 50 & \\
\hline Shrimp & $\begin{array}{l}\text { Banana shrimp } \\
\text { (Fenneropenaeus } \\
\text { merguiensis) }\end{array}$ & $100^{\mathrm{b}}$ & 30 & - & 7 & 3 & - & 2 & \\
\hline
\end{tabular}

${ }^{\mathrm{a}}$ The number is equal to the sum of the weight of the skin and the scales

${ }^{\mathrm{b}}$ The number of shrimp per $1 \mathrm{~kg}(1000 \mathrm{~g})$

higher price of shrimp compared to fish, at the time of the study (2018), has made it difficult for low-income groups to buy enough shrimp [31]; also, edible parts of $1 \mathrm{~kg}$ of shrimp is less than $1 \mathrm{~kg}$ of fish, which can be another reason for this result. In other words, although the financial situation of households has not been measured in our study, the results show that the economic situation of the family has affected shrimp consumption so that people with illiterate education and uncertain jobs have shown less consumption than other groups. However, studies have also pointed to the role of the economy in the food security of Bushehrian families [32-34].

\section{Waste generation factor}

According to the designed questionnaire (the first way), results obtained from sellers' estimation showed that the average of produced fish wastes was $252 \mathrm{~g} / \mathrm{kg}$ of raw fish and the average production waste of shrimp was about $490 \mathrm{~g} /$ $\mathrm{kg}$. Since they were a subjective estimation, we use the accurate laboratory method (the second way) to weight the fish and shrimp wastes (Fig. 2). The results were obtained by weighing of all parts of the wastes separately, then, they were reduced from the total raw fish and shrimp weights (Table 4). For 6 types of selected fishes, the minimum generated waste was obtained $18.18 \%$ for Shir (Scomberomorus commerson) and the maximum was obtained $42.4 \%$ for Shery (Lethrinus nebulosus). The average of fish generated wastes was obtained $32.67 \%$, which was close to the estimated quantity from sellers in our study and the percentage of fish generated waste in Italy (30\%) [7]. In addition, it was obtained for shrimp about $42 \%$ in the same way, which was very close to the estimated quantity of sellers in our study (49\%). Various articles have reported different percentages of fish waste generation such as $14 \%$ [35], $40 \%$ [36], and $20-80 \%$ [37, 38], depending on the type of fish in each area, the types of fish parts used in the waste calculation, and culture of people. In our study, the bone sector has not considered as a household and stores' wastes, but some countries like Japan consumed fillet of fish (without bones) in their traditional foods (Shashami) [3]. In Iran, there is no exact figure of fish and shrimp wastes rate; based on our knowledge, only Shadan (2007) mentioned that $40 \%$ of fishes in Iran converted to wastes [36, 39], which is nearly similar to our result. Furthermore, articles have stated that shrimp processing generated from 40 to $80 \%$ waste [40]. Based on Sachindra (2005), it was between 48 and $56 \%$ in Indian shrimp [41]. 
Table 5 A brief description of triple waste generation scenarios

$\begin{array}{llllll}\begin{array}{l}\text { Fish-generated } \\ \text { waste (ton/y) }\end{array} & \begin{array}{l}\text { Shrimp-generated } \\ \text { waste (ton/y) }\end{array} & \begin{array}{l}\text { Total generated } \\ \text { waste (ton/y) }\end{array} & \begin{array}{l}\text { Total collection } \\ \text { waste }(\text { ton/y })^{\mathrm{a}}\end{array} & \begin{array}{l}\text { Bio-gas production } \\ \text { potential (L/kg VS) }\end{array} & \begin{array}{l}\text { Bio-diesel produc- } \\ \text { tion potential (mil- } \\ \text { lion L) }\end{array}\end{array}$

\begin{tabular}{|c|c|c|c|c|c|c|}
\hline \multicolumn{7}{|l|}{ This study } \\
\hline Scenario 1 & 1982 & 1749 & 3731 & 3731 & - & - \\
\hline Scenario 2 & 5105 & 3698 & 8803 & 8803 & - & - \\
\hline Scenario 3 & 20,040 & 9347 & 29,388 & 29,388 & 600 & 23 \\
\hline Kafle et al. [9] & - & - & - & - & $671-763$ & - \\
\hline Xu et.al. [43] & - & - & - & - & 409.5 & - \\
\hline $\begin{array}{l}\text { Ardebili and } \\
\text { Khademalrasoul } \\
\text { [36] }\end{array}$ & - & - & - & - & - & 26 \\
\hline
\end{tabular}

${ }^{\mathrm{a}}$ Assuming the complete collection of all produced wastes

\section{Triple waste estimation scenarios}

Based on Scenario 1, to estimate the total fish sales by stores in each season, we assumed that the number of sales was constant in different months of a season. Therefore, the existing statistics of each month are tripled and finally the total quantity of sold fish was estimated for four seasons equal to 2400 ton/year. Since this quantity of fish was related to 91 participating fish stores, the total quantity of sales for a total of 230 fish stores in the whole province was equal to 6066 ton/year. Furthermore, according to the sale of 1648 tons of shrimp per year for 91 participating shops, the total sales was 4165 ton/year. Finally, taking into account the generation factor of fish and shrimp waste obtained in the previous stage, the quantity of fish and shrimp waste based on the total sold was equal to 1982 and 1749 ton/year, respectively (Table 5). Similar to our study, the quantity of sold fish in the Rimini markets in Italy was calculated; then, the potential availability of sold fish in Emilia-Romagna was obtained by extrapolation. The total quantity of waste in Rimini province and Emilia region were estimated equal 14.3 and $195 \mathrm{Mg} /$ year, respectively [7]. Based on Garcia (2005), daily fish wastes generated in the small establishments of the Salamanca city (Spain) were collected and weighed for 9 months; the quantity of fish generated waste were estimated with this formula: $\left(\mathrm{kg} \times(\text { no. establishment })^{-1} \times \mathrm{d}^{-1}\right)$ [22].

Based on Scenario 2, to estimate the total aquatic consumption, we assumed that the consumption is constant in different months of a season. Therefore, the quantity of 1 month was tripled and the total quantity of consumed fish and shrimps was estimated equal to 50 and 28 ton/ year, respectively. Since this quantity of fish and shrimp consumption was related to 636 households participating in the study, the total consumption quantity for the total 257,950 households in the whole province were equal to 20,562 and 11,586 ton/year, respectively. As mentioned, due to lack of our access to actual statistics of total households' consumption in a year, we had to estimate annual values based on 1-month data reported by the participants in each season. In addition, $76 \%$ of the households cleaned and peeled the fish and shrimps at their home to remove the wastes; for the rest of the households (26\%), this operation is done in the place of purchase (in stores). Considering the coefficient of $76 \%$ and the fish and shrimp waste generation factors, the quantities of 5105 and 3698 tons per year of fish and shrimp waste are produced by all households, respectively (Table 5). In the Italian study, to calculate the total production fish wastes in the full region, extrapolation was done by multiplying the quantity of fish consumption in the Emilia-Romagna scale by an expected residues production of $30 \%$ in weight [7].

In Scenario 3, according to the available official statistics on the amount of capturing and aquaculture, the quantity of them was reported equal 83,600 ton/year in 2018 [13]. Based on the obtained waste generation factors, the number of generation wastes was equal to 20,040 and 9347 ton/year for fish and shrimp, respectively (Table 5). In some articles, this model has been used to estimate the quantity of produced wastes; even it has been used in the fish waste estimation from the global statistics of fish production provided by the FAO $[11,18]$. Therefore, due to the comprehensiveness of this model, the quantity of wastes resulting from this scenario was considered equal to the total fish- and shrimp-generated waste in the province. On the other hand, the sum of two Scenarios (1 and 2 ) are given inside the Scenario 3. The remaining quantity is related to other unaccounted sectors such as fish industries, and fish and shrimp being transferred to other provinces, shrimp breeding and cultural ponds, and vendors. 

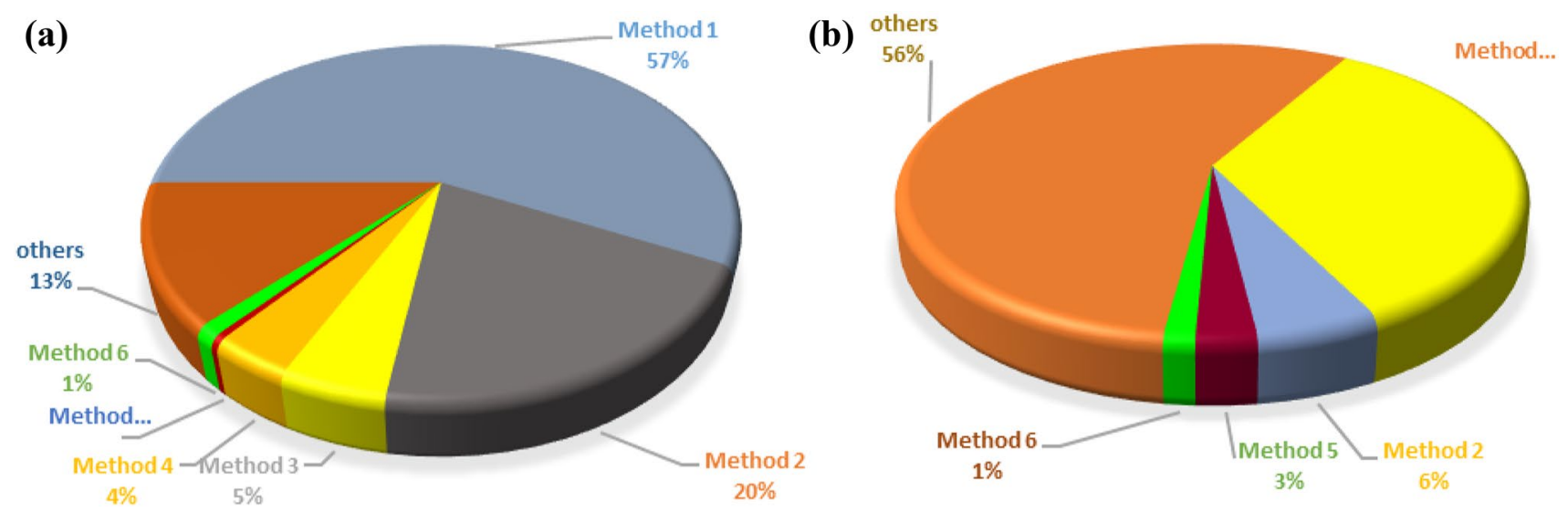

Fig. 3 Fish and shrimp waste disposal methods: a for households and $\mathbf{b}$ for stores

\section{Waste disposal methods: an energy estimation}

Results showed that more than half of the households (57\%) dispose their fish and shrimp wastes with other daily household wastes (Method 1). Willingness to perform other methods such as feeding domestic or wild animals (such as cats) (20\%) (Method 2), transfer to municipal landfill by individuals to prevent bad odor (5\%) (Method 3), burial in soils (especially garden) as fertilizer (4\%) (Method 4), direct dumping at sea $(0.5 \%)$ (Method 5) and $1 \%$ related in other ways (Method 6) were identified in the participants' responses (Fig. 3a). According to the observed results of the fish and shrimp sellers on waste disposal, about (34\%) fish and shrimp wastes are delivered daily to the municipal solid waste collection system (Method 1). The tendency to perform other methods such as feeding domestic or wild animals (such as cats) (6\%) (Method 2), direct dumping at sea (3\%) (Method 5), and 1\% related to other Methods (Method 6) were identified in the participants' responses (Fig. 3b).

Green et al. (1997) have considered some methods for disposing of fish and shrimp wastes, such as dumping/dispersing at sea and landfilling. In some of them, like dumping at sea, there has been strong opposition by environmentalists [40]. According to the statistics of the Iran Fisheries Organization, 47 factories are producing standard fish powder [13], some of them are in Bushehr province which is one of the used solutions as a feed meal. In addition, some other most usual alternative management methods such as anaerobic digestion, gasification, biofuel production, composting, and incineration can be used instead of landfilling [22, 26, 27, 42].

Anaerobic digestion as a biochemical process can be done in a direct-digestion or co-digestion. Some direct-digestion study on fish wastes have obtained biogas or methane yield of $361 \mathrm{Nm}^{3} \mathrm{CH} 4 / \mathrm{Mg}$ VS [7], 671-763 mL biogas/g VS and $441-482 \mathrm{~mL} \mathrm{CH} 4 / \mathrm{g}$ VS [9]. The yield of generated biogas in a co-digestion process have been obtained for fish waste and bagasse (409.5 mL biogas/g VS) [43] and fish waste and sisul pulp $\left(0.62 \mathrm{~m}^{3} \mathrm{CH} 4 / \mathrm{kg}\right.$ VS) [24]. The yield of all these methods depends on various factors, including the type of fish, the amount of TS (total solid), VS (volatile solids), protein and lipid content. [44]. Unfortunately, in the studies conducted in Iran's fish wastes, no information was found about the physicochemical characterization of fish waste. To estimate the biogas production potential via an anaerobic digestion, we assume the amount of TS and VS of Bushehr fish wastes equal to $25 \%$ and $89 \%$, respectively, which are similar to the study of Colombia's fish wastes [44]. In addition, according to Moreda et al. (2016), it is assumed that the average amount of methane produced per kilogram of fish wastes was 390 (L CH4/kg VS) [24, 45]. With considering that methane is about 65\% [9] of biogas content, the produced biogas per kilogram of Bushehr fish wastes is estimated 600 (L biogas $/ \mathrm{kg} \mathrm{VS})$. Moreover, the average of biogas energy content equal to $6 \mathrm{KWh} / \mathrm{m}^{3}$ [44] was used for the calculations. Based on Bushehr's estimated fish waste production of about 20,040 ton/year, the estimated potential for biogas production from these wastes will be $2,675,400 \mathrm{~m}^{3} /$ year, which can equivalent to $16,052 \mathrm{MWh}$. Furthermore, by assuming the biogas conversion coefficient of $45 \%$ to thermal energy and 35\% to electrical energy [44], about 7223 MWh thermal energy and 5618 MWh electrical energy will be obtained.

On the other hand, transesterification (as a chemical processes) is used to produce biofuels [46]. Based on our results, Bushehr province had a total estimated waste of about 29,388 tons per year. By assuming the conversion coefficient wastes to biodiesel nearly $65 \%$ [36], the potential of produced biodiesel equivalent to 19,102 tons of oil (19 kt) is obtained, which is about 23 million L of oil. It is approximately $4.2 \%$ of the total diesel fuel requirement of the province in 2016 (545 million L) [47]. This amount of produced biodiesel will be able to supply about $10 \%$ of the 
total consumption of diesel in the province's transportation sector.

\section{Conclusion}

It seems that the present study is the first article in Iran conducted to estimate the quantity of fish- and shrimp-produced waste and waste generation factor in Bushehr province. The waste generation factor of fish and shrimp was obtained equal to $32.67 \%$ and $42 \%$, respectively. Based on three scenarios, the quantity of fish- and shrimp-generated waste was estimated. We concluded that scenario 3 is comprehensive enough, so that it include the produced waste quantities of the other two scenarios. Therefore, the quantity of waste produced in the province was estimated equal 29,388 tons/ years. The most common way to dispose of wastes in both households and stores was through the municipal waste collection system (landfilling). In addition, the estimated potential for biogas production was $2,675,400 \mathrm{~m}^{3} /$ year, which is equivalent to $16,052 \mathrm{MWh}$. On the other hand, the potential of biodiesel production was obtained equivalent to 19,102 tons of oil (19 kt), which is about $4.2 \%$ of the total diesel fuel requirement of the province in 2016. Likewise, it is able to supply about $10 \%$ of the total consumption of diesel in the province's transportation sector.

We used the estimated values for some of the main variables in this study because of the data limitation. By the way, more detailed studies are suggested. It needs to calculate the actual amount of fish- and shrimp-produced waste in all generation sources, determine the physicochemical properties of these wastes, assess the ability of them to produce energy on real wastes, etc. Furthermore, encouraging and allowing the private sector entering in to this issue or strengthening the public sector to collect and recycle of these wastes are expected.

Supplementary Information The online version contains supplementary material available at https://doi.org/10.1007/s10163-021-01219-2.

Acknowledgements The authors would like to thank the Research Deputy of Tehran University of Medical Sciences for financial support of research study as Grant \# 49258, as well as all the databases of the International and Iranian Departments and/or Organizations.

\section{References}

1. Nahman A, De Lange W, Oelofse S, Godfrey L (2012) The costs of household food waste in South Africa. Waste Manag 32(11):2147-2153

2. Thi NBD, Kumar G, Lin C-Y (2015) An overview of food waste management in developing countries: Current status and future perspective. J Environ Manag 157:220-229
3. Nagai T, Suzuki N (2000) Isolation of collagen from fish waste material-skin, bone and fins. Food Chem 68(3):277-281

4. FAO (2013) Food wastage footprint. Impacts on Natural Resources. Summary Report. http://www.fao.org/3/a-i3991e.pdf. Accessed 19 Jul 2020

5. Tonini D, Albizzati PF, Astrup TF (2018) Environmental impacts of food waste: learnings and challenges from a case study on UK. Waste Manag 76:744-766

6. Ebenezer AV, Kumar MD, Kavitha S, Banu JR (2020) State of the art of food waste management in various countries. Food waste to valuable resources. Academic Press, Cambridge, pp 299-323

7. Greggio N, Carlini C, Contin A, Soldano M, Marazza D (2018) Exploitable fish waste and stranded beach debris in the EmiliaRomagna Region (Italy). Waste Manag 78:566-575

8. Yano Y, Oikawa H, Satomi M (2008) Reduction of lipids in fish meal prepared from fish waste by a yeast Yarrowia lipolytica. Int J Food Microbiol 121(3):302-307

9. Kafle GK, Kim SH, Sung KI (2013) Ensiling of fish industry waste for biogas production: a lab scale evaluation of biochemical methane potential (BMP) and kinetics. Bioresour Technol 127:326-336

10. Ward AJ, Løes A-K (2011) The potential of fish and fish oil waste for bioenergy generation: Norway and beyond. Biofuels 2(4):375-387

11. Kannan S, Gariepy Y, Raghavan GSV (2017) Optimization and characterization of hydrochar produced from microwave hydrothermal carbonization of fish waste. Waste Manag 65:159-168

12. FAO (2016) The State of World Fisheries and Aquaculture 2016: Contributing to food security and nutrition for all. Technical Report. Rome http://www.fao.org/publications/sofia/2016/en/. Accessed 10 Jul 2020

13. IFO (2019) Statistics Yearbook. Iran Fisheries Organization Statistics 2013-2018. http://www.shilat.com/Articlefile/.pdf. Accessed 19 Jul 2020

14. IFO (2017) Statistics Yearbook. Iran Fisheries Organization Statistics 2012-2016. http://www.shilat.com. Accessed 17 Jul 2020

15. FAO (2019) FAO Yearbook. Fishery and Aquaculture Statistics 2017. http://www.fao.org/fishery/static/Yearbook/YB2017_ USBcard/index.htm.\%0D. Accessed 19 Jul 2020

16. FAO (2020) Fishery and Aquaculture Country Profiles: Iran (Islamic Rep. of) (2015). Country Profile Fact Sheets in FAO Fisheries and Aquaculture Department. http://www.fao.org/fishe ry/. Accessed 19 Jul 2020

17. Mo WY, Man YB, Wong MH (2018) Use of food waste, fish waste and food processing waste for China's aquaculture industry: needs and challenge. Sci Total Environ 613:635-643

18. Saranya R, Selvi AT, Jayapriya J, Aravindhan R (2020) Synthesis of fat liquor through fish waste valorization, characterization and applications in tannery industry. Waste Biomass Valor 11:1-11

19. Akbari H, Jorfi S, Mahvi AH, Yousefi M, Balarake D (2018) Adsorption of fluoride on chitosan in aqueous solutions: determination of adsorption kinetics. Fluoride 51:319-327

20. Azari A, Gharibi H, Kakavandi B, Ghanizadeh G, Javid A, Mahvi AH et al (2017) Magnetic adsorption separation process: an alternative method of mercury extracting from aqueous solution using modified chitosan coated $\mathrm{Fe} 3 \mathrm{O} 4$ nanocomposites. J Chem Technol Biotechnol 92:188-200

21. Ghanbarian M, Ghanbarian M, Mahvi AH, Tabatabaie T (2020) Enhanced fluoride removal over $\mathrm{MgFe} 2 \mathrm{O} 4$-chitosan-CaAl nanohybrid: Response surface optimization, kinetic and isotherm study. Int J Biol Macromol 148:574-590

22. Garcia AJ, Esteban MB, Marquez MC, Ramos P (2005) Biodegradable municipal solid waste: Characterization and potential use as animal feedstuffs. Waste Manag 25(8):780-787

23. He R, Yao X-Z, Chen M, Ma R-C, Li H-J, Wang C et al (2018) Conversion of sulfur compounds and microbial community 
in anaerobic treatment of fish and pork waste. Waste Manag 76:383-393

24. Mshandete A, Kivaisi A, Rubindamayugi M, Mattiasson BO (2004) Anaerobic batch co-digestion of sisal pulp and fish wastes. Bioresour Technol 95(1):19-24

25. Yang L, Zhang A, Zheng X (2009) Shrimp shell catalyst for biodiesel production. Energy Fuels 23(8):3859-3865

26. Yahyaee R, Ghobadian B, Najafi G (2013) Waste fish oil biodiesel as a source of renewable fuel in Iran. Renew Sustain Energy Rev 17:312-319

27. Kraiem T, Ben H-T, Naoui S, Belayouni H, Jeguirim M (2015) Characterization of the liquid products obtained from Tunisian waste fish fats using the pyrolysis process. Fuel Process Technol 138:404-412

28. BMO (2020) The climate of the province at a glance. Bushehr Meterological Organization. http://www.bushehrmet.ir/SC.php? type $=$ static\&id $=10$. Accessed 19 Jul 2020

29. Dabbaghiyan A, Fazelpour F, Abnavi MD, Rosen MA (2016) Evaluation of wind energy potential in province of Bushehr, Iran. Renew Sustain Energy Rev 55:455-466

30. Minitab19-support. Interpret the key results for Chi-Square Test for Association. https://support.minitab.com/en-us/minitab/19/ help-and-how-to/statistics/tables/how-to/chi-square-test-for-assoc iation/interpret-the-results/key-results/. Accessed 29 Dec 2020

31. BFO (2018) The ups and downs of the decline in fishing and the increase in shrimp prices in the province. Bushehr Provienc Fisheries Organization. http://www.shilat-bushehr.ir/fa/posts/1066. Accessed 18 Jul 2020

32. Mohammadpour Kaldeh M, Fouladvand M, Avakh Keisami M (2010) Food insecurity as a risk factor for obesity in low-income Boushehrian women. ISMJ 13(4):263-272

33. Yeganeh S, Motamed N, NajafpourBoushehri S, Ravanipour M (2018) Assessment of the knowledge and attitude of infants' mothers from Bushehr (Iran) on food security using anthropometric indicators in 2016: a cross-sectional study. BMC Public Health 18(1):621

34. Yeganeh S, Motamed N, Boushehri SN, Ravanipour M (2019) Study of demographic characteristics related to food insecurity in Bushehr Iran households with infants aged 1-2 years. J Pediatr Nurs 6(1):9-16

35. Sathivel S, Prinyawiwatkul W, Grimm CC, King JM, Lloyd S (2002) FA composition of crude oil recovered from catfish viscera. J Am Oil Chem Soc 79(10):989-992
36. Ardebili SMS, Khademalrasoul A (2018) An analysis of liquidbiofuel production potential from agricultural residues and animal fat (case study: Khuzestan Province). J Clean Prod 204:819-831

37. Ghaly AE, Ramakrishnan VV, Brooks MS, Budge SM, Dave D (2013) Fish processing wastes as a potential source of proteins. Amin Acids Oils Crit Rev J Microb Biochem Technol 5(4):107-129

38. Madhu D, Arora R, Sahani S, Singh V, Sharma YC (2017) Synthesis of high-quality biodiesel using feedstock and catalyst derived from fish wastes. J Agric Food Chem 65(10):2100-2109

39. Shadan A (2007) Economic Analysis of Agricultural Waste in Iran. In: 6th National Conference of Agricultural Economics Mashhad, Iran. https://www.civilica.com/Paper-IAEC06IAEC06_020.html. Accessed 19 Jul 2020

40. Green JH, Mattick JF (1977) Possible methods for the utilization or disposal of fishery solid wastes. J Food Qual 1(3):229-251

41. Sachindra NM, Bhaskar N, Mahendrakar NS (2005) Carotenoids in different body components of Indian shrimps. J Sci Food Agric 85(1): 167-172

42. Bücker F, Marder M, Peiter MR, Lehn DN, Esquerdo VM, de Almeida Pinto LA et al (2020) Fish waste: an efficient alternative to biogas and methane production in an anaerobic mono-digestion system. Renew Energy 147:798-805

43. Xu J, Mustafa AM, Sheng K (2017) Effects of inoculum to substrate ratio and co-digestion with bagasse on biogas production of fish waste. Environ Technol 38(20):2517-2522

44. Cadavid-Rodríguez LS, Vargas-Muñoz MA, Plácido J (2019) Biomethane from fish waste as a source of renewable energy for artisanal fishing communities. Sustain Energy Technol Assess 34:110-115

45. Moreda IL (2016) The potential of biogas production in Uruguay. Renew Sustain Energy Rev 54:1580-1591

46. Shirzad M, Panahi HKS, Dashti BB, Rajaeifar MA, Aghbashlo M, Tabatabaei M (2019) A comprehensive review on electricity generation and GHG emission reduction potentials through anaerobic digestion of agricultural and livestock/slaughterhouse wastes in Iran. Renew Sustain Energy Rev 111:571-594

47. NIOPDC (2016) Statistical Bulletin of Iran's Consomption of Oil Productions. https://niordc.ir/uploads/amarname95.pdf. Accessed 19 Jul 2020

Publisher's Note Springer Nature remains neutral with regard to jurisdictional claims in published maps and institutional affiliations.

\section{Authors and Affiliations}

\section{Masoumeh Ravanipour ${ }^{1,2} \cdot$ Razieh Bagherzadeh $^{3} \cdot$ Amir Hossein Mahvi $^{1,4}(\mathbb{C}$}

Masoumeh Ravanipour

m.ravanipour@bpums.ac.ir

Razieh Bagherzadeh

raziehbagherzadeh@yahoo.com

1 Department of Environmental Health Engineering, School of Public Health, Tehran University of Medical Sciences, PourSina St., Qods St., Enghelab St., Tehran 141761315, Iran
2 Department of Environmental Health Engineering, Faculty of Health and Nutrition, Bushehr University of Medical Sciences, Bushehr, Iran

3 Department of Midwifery, Faculty of Nursing and Midwifery, Bushehr University of Medical Sciences, Bushehr, Iran

4 Center for Solid Waste Research (CSWR), Institute for Environmental Research (IER), Tehran University of Medical Sciences, Tehran, Iran 